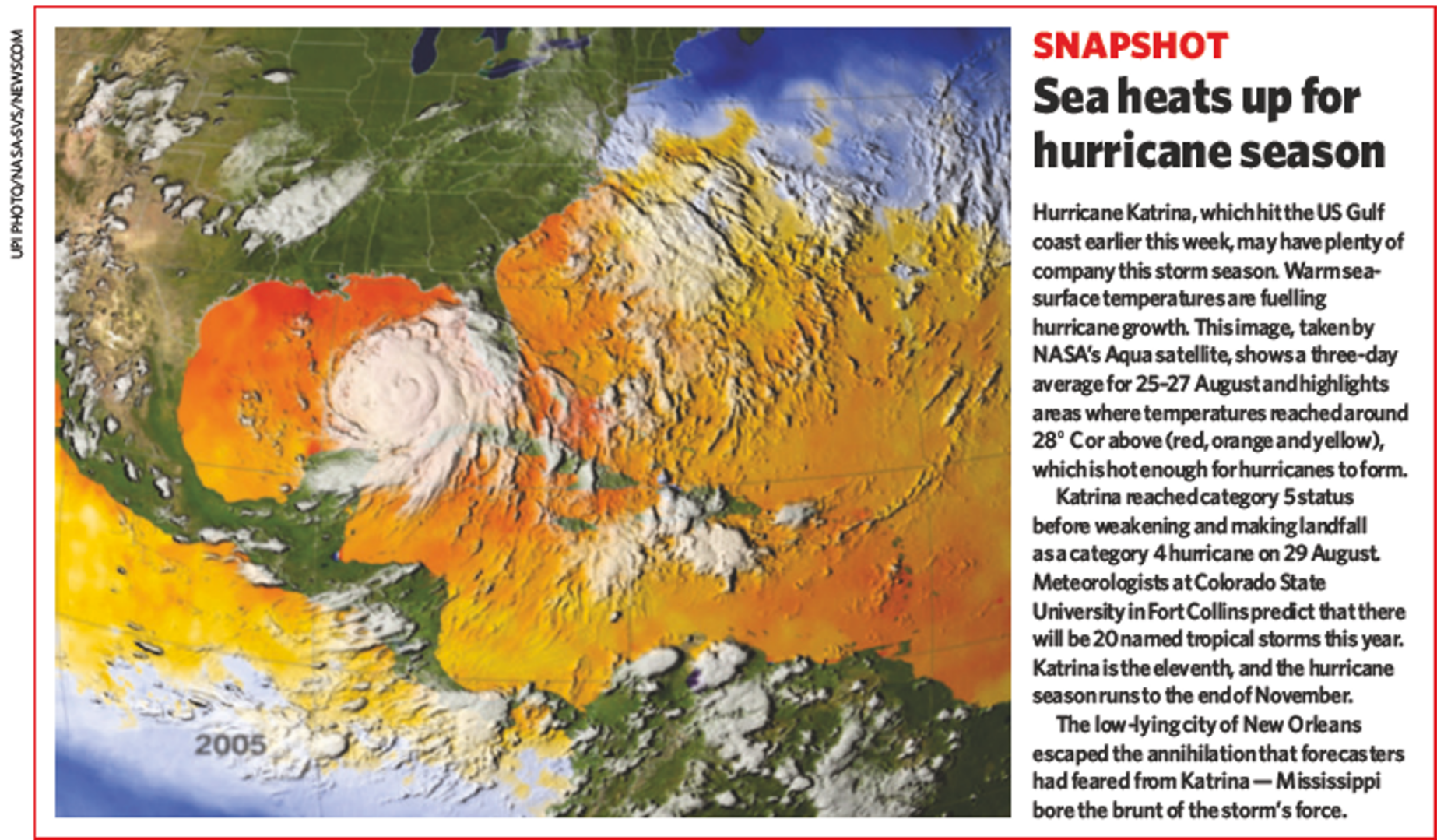

\title{
Hospital closure puts tissue bank in jeopardy
}

WASHINGTON DC

The world's largest tissue repository is without a home after a review panel decided to close the military hospital where it is based.

Scientists and pathologists met this week to try to influence the fate of the tissue bank at the Armed Forces Institute of Pathology (AFIP) in Washington DC.

The collection contains some 90 million samples, including those of rare tumours and diseases that can be used to develop new therapies, says David Seckinger, president of the Washington-based American Registry of Pathology. ${ }^{\alpha}$ The repository is unique, he says. "Its value to the American medical community is unparalleled."

The collection began in 1862 as part of a museum for disease specimens taken from Civil War soldiers. Over the years the institute expanded; it played key roles, for instance, in the study of the 1918 flu epidemic, Gulf War Syndrome, and in identifying victims of the terrorist attacks on 11 September 2001.

But the AFIP has long faced budget cutbacks (see Nature 424, 4-5; 2003), and earlier this year its host, the Walter Reed Army Medical Center, came into the crosshairs of the
Base Realignment and Closure Commission.

This independent commission periodically reviews operations at hundreds of US military bases and determines which should be closed. As part of the latest round of cutbacks, the commission voted on 25 August to permanently close Walter Reed's main campus in Washington. The panel recommended moving some AFIP functions, such as its forensics division, to Dover Air Force Base in Delaware, and preserving others, such as the tissue repository - but it offered no guidance on how to do the latter.

Without institute pathologists running the collection, it could fall into disuse and disrepair, says William Travis, a former AFIP pathologist now at the Memorial SloanKettering Cancer Center in New York.

As Nature went to press, a coalition of pathology societies and other interest groups were due to meet to draw up a set of recommendations for the collection's future. The possibilities include attaching the repository to another government agency, such as the National Institutes of Health, or bringing it under the purview of a public-private consortium. “There has been a flurry of different ideas and thoughts as to how it might be used," says Seckinger.

Some change might be good, says Renu Virmani, a former AFIP pathologist now at the International Registry of Pathology in Gaithersburg, Maryland Currently, the collection is available for use only by the institute's 800 employees and their collaborators. A move could open the repository up for broader study.
"The repository is unique. Its value to the American medical community is unparalleled."
Ultimately, the Department of Defense will decide the tissue bank's fate. Travis, for one, is concerned that the department may try to warehouse the contents of the collection. "The repository is a living organism," he argues. "It is most meaningful in the hands of the top experts in the world."

Whatever happens to the AFIP, the Walter Reed centre is unlikely to be spared. The Base Realignment and Closure Commission will send its list of closures to President George W. Bush later this month. He is expected to sign it, giving Congress 45 days to reject the closures, which will otherwise become law.

Geoff Brumfiel 